\title{
Could road constructions be more hazardous than an earthquake in terms of mass movement?
}

\author{
Hakan Tanyaş $^{1}$ (D) $\cdot$ Tolga Görüm $^{3}$ (D) $\cdot$ Dalia Kirschbaum² ${ }^{2}$. Luigi Lombardo ${ }^{1}$ (D)
}

Received: 15 July 2021 / Accepted: 29 December 2021 / Published online: 6 January 2022

(c) The Author(s) 2022

\begin{abstract}
Roads can have a significant impact on the frequency of mass wasting events in mountainous areas. However, characterizing the extent and pervasiveness of mass movements over time has rarely been documented due to limitations in available data sources to consistently map such events. We monitored the evolution of a road network and assessed its effect on mass movements for a 11-year window in Arhavi, Turkey. The main road construction projects run in the area are associated with a hydroelectric power plant as well as other road extension works and are clearly associated with the vast majority (90.1\%) of mass movements in the area. We also notice that the overall number and size of the mass movements are much larger than in the naturally occurring comparison area. This means that the sediment load originating from the anthropogenically induced mass movements is larger than its counterpart associated with naturally occurring landslides. Notably, this extra sediment load could cause river channel aggregation, reduce accommodation space and as a consequence, it could lead to an increase in the probability and severity of flooding along the river channel. This marks a strong and negative effect of human activities on the natural course of earth surface processes. We also compare frequency-area distributions of humaninduced mass movements mapped in this study and co-seismic landslide inventories from the literature. By doing so, we aim to better understand the consequences of human effects on mass movements in a comparative manner. Our findings show that the damage generated by the road construction in terms of sediment loads to river channels is compatible with the possible effect of a theoretical earthquake with a magnitude greater than $M_{w}=6.0$.
\end{abstract}

Keywords Anthropocene - Human-induced mass movements · Road construction · Rainfall-induced landslides $\cdot$ Earthquake-induced landslides

Hakan Tanyaş

h.tanyas@utwente.nl

1 Faculty of Geo-Information Science and Earth Observation (ITC), University of Twente, Enschede, Netherlands

2 Hydrological Sciences Laboratory, NASA Goddard Space Flight Center, Greenbelt, MD, USA

3 Eurasia Institute of Earth Sciences, Istanbul Technical University, Istanbul, Turkey 


\section{Introduction}

Recent findings suggest that our planet has been going through a new geologic time, "Anthropocene," in which human-driven changes dominate the Earth system and its geological records instead of natural processes (Lewis and Maslin 2015; Steffen et al. 2015). The existence of the "Anthropocene" is supported by the "Great Acceleration" graphs showing proxies of growing human activities (e.g., population, water use, transportation, etc.) and their influence on natural systems (e.g., $\mathrm{CO}_{2}$ emission, surface temperature, domesticated land, etc.), which becomes quite obvious since the mid-twentieth century (Steffen et al. 2011, 2015) and is functionally and stratigraphically distinct from the Holocene epoch (Waters et al. 2016). However, the existence of the "Anthropocene" still needs much evidence (Brown et al. 2013). Notably, soil erosion, as a geomorphologic process, has an essential role in the formation of the geological records. In fact, soil erosion in the "Anthropocene" is chiefly governed by the coupled effect of natural and human-induced soil erosion processes (Poesen 2018). In this context, we still need to better understand the interactions between these processes (Brown et al. 2017).

In seismically active mountain ranges, landslides appear as the major erosive agent (e.g., Dadson et al. 2004; Morin et al. 2018; Parker et al. 2011). Moreover, anthropogenic factors (i.e., land-use change, deforestation, hill cutting, etc.) can also be a significant contributor of landslide initiations in active mountain ranges (Maharaj 1993; Larsen and Parks 1997; Wasowski 1998; Chang and Slaymaker 2002; Guns and Vanacker 2014; Holcombe et al. 2016; Laimer 2017; Vuillez et al. 2018; Lee and Winter 2019; Li et al. 2020). In particular, road construction is reported as one of the most influential factors of mass movement and, in particular, landslide occurrence in seismically active mountainous regions such as in India (e.g., Haigh et al. 1989; Barnard et al. 2001), Nepal (e.g., Hearn and Shakya 2017; McAdoo et al. 2018), New Zealand (e.g., Coker and Fahey 1993; Fransen et al. 2001), Pakistan (e.g., Owen et al. 2008; Atta-ur-Rahman et al. 2011) and Taiwan (e.g., Chang and Slaymaker 2002; Chen and Chang 2011). This is not surprising because hillslope cutting can cause a reduction in shear strength of hillslope material, disturb water flow directions and also raised or perched water tables that lead to increase pore water pressure in case of rainfall event (e.g., Guadagno et al. 2003; Tarolli et al. 2013; Holcombe et al. 2016).

As a result, an increasing number of slope failures are observed in seismically active mountain ranges such as the Himalayan region because of road construction (Petley et al. 2007; Froude and Petley 2018). However, capturing the anthropogenic effect in landslide occurrence may not be a trivial task in such environments, because seismic shaking disturbs hillslope materials and increases landslide susceptibility irrespective of road construction (Owen et al. 2008; Tang et al. 2011). Therefore, differentiating the signal of anthropogenic effect from the seismic one can be a challenge in some cases. For instance, Khattak et al. (2010) and Khan et al. (2013) examine the post-seismic landslide evolution following the 2005 Kashmir earthquake and emphasize the possible confusion between landslides triggered by road construction and strength reduction caused by seismic shaking. The same difficulty distinguishing the contribution of anthropogenic and seismic factors in landslide occurrence can also be valid for slope failures that occurred following the 2015 Gorkha earthquake. Rosser et al. (2021) and Jones et al. (2020) report an increased landslide rate from 2016/2017 onward, which is argued to be primarily associated with the increase in road-construction efforts. However, the disturbance induced by the earthquake is inevitably a part of the predisposing factors. 
This implies that capturing the anthropogenic effect could be more convenient in an environment at which seismicity does not play a significant role in landslide occurrence. Therefore, in this study, we focus on a mountainous area located in the northeastern part of Turkey, where the site has been exposed to no significant seismicity but to multiple road construction projects. We examine not only expanding roads, but also mass movements associated with those roads over the last 11 years. To assess the role of the anthropogenic effect, we also map landslides that do not show any direct relation with roads. Ultimately, we compare our mass movement inventory triggered by hillslope cutting with landslide inventories associated with earthquakes in terms of their total surface areas. We should stress that this comparison is only valid for long-term or secondary effects of both human-induced mass movements and earthquake-induced landslides. Because, regardless of their direct consequences, both cases increase the downstream sediment loads in a river network. And this could lead not only to river channel aggregation but also to increase the probability and severity of flooding along the river channel (Fan et al. 2019). In other words, we consider the total surface area of mass movements and landslides as proxies for the long-term hazardous effects of these processes. Therefore, by this comparison, we aim to test the hypothesis that human-induced factors, in our case road constructions, could be more hazardous than an earthquake in terms of mass movements. We test this hypothesis to better assess how relevant human influence can be compared to natural processes.

We also stress that the construction projects conducted in the target area of this research are met with resistance from both non-governmental environmental organizations (e.g., WWF 2020) and geoscientific community (Akbulut and Kurdoglu 2015), because the study area is within the Caucasus ecoregion, which is one of the world's 34 biodiversity hotspots (Şekercioğlu et al. 2011a). The Kamilet Valley crossing through the study area (Sub-basins 4, 5 and 9 in Fig. 1) is one of the sites reflecting the rich biodiversity of the region. It hosts numbers of endemic and rare non-endemic plants species that need to be protected (Şekercioğlu et al. 2011b; Akbulut and Kurdoglu 2015; Yuksel and Eminagaoglu 2017). Therefore, the research question of this study - that aims at exploring the anthropogenic control on mass wasting processes-also has implications on the protection and sustainable development of a biodiversity hot spot.

\section{Study area}

The study area is located in the northeastern part of Turkey within the municipal boundaries of Findıkl1, Rize, and Arhavi, Artvin. It comprises nine catchments over approximately $195 \mathrm{~km}^{2}$ (Fig. 1). Overall, the alternation of basalt-andesitic lava, pyroclastics, sandstone, marl, and clayey limestone are present throughout the area (Alan et al. 2019).

The steep topographic features of the site are coupled with a strong precipitation regime. The study area is within the zone receiving the highest precipitation measured throughout Turkey (Fig. 2a). Based on the 20 years (from 2000-06-01 to 2020-03-31) time series of the Integrated Multi-Satellite Retrievals (IMERG) Final Run product (Huffman et al. 2019), which is available through Giovanni (v.4.32) (Acker and Leptoukh 2007) online data system, the average monthly precipitation of strong events (i.e., above 0.95 quantile) is $353 \pm 40 \mathrm{~mm} / \mathrm{month}$. Precipitation measurements are also available from 2012 onward (from 2012-09-04 to 2020-05-31) via three rainfall stations located nearby the study area (Fig. 2b). Based on those measurements, the average daily 


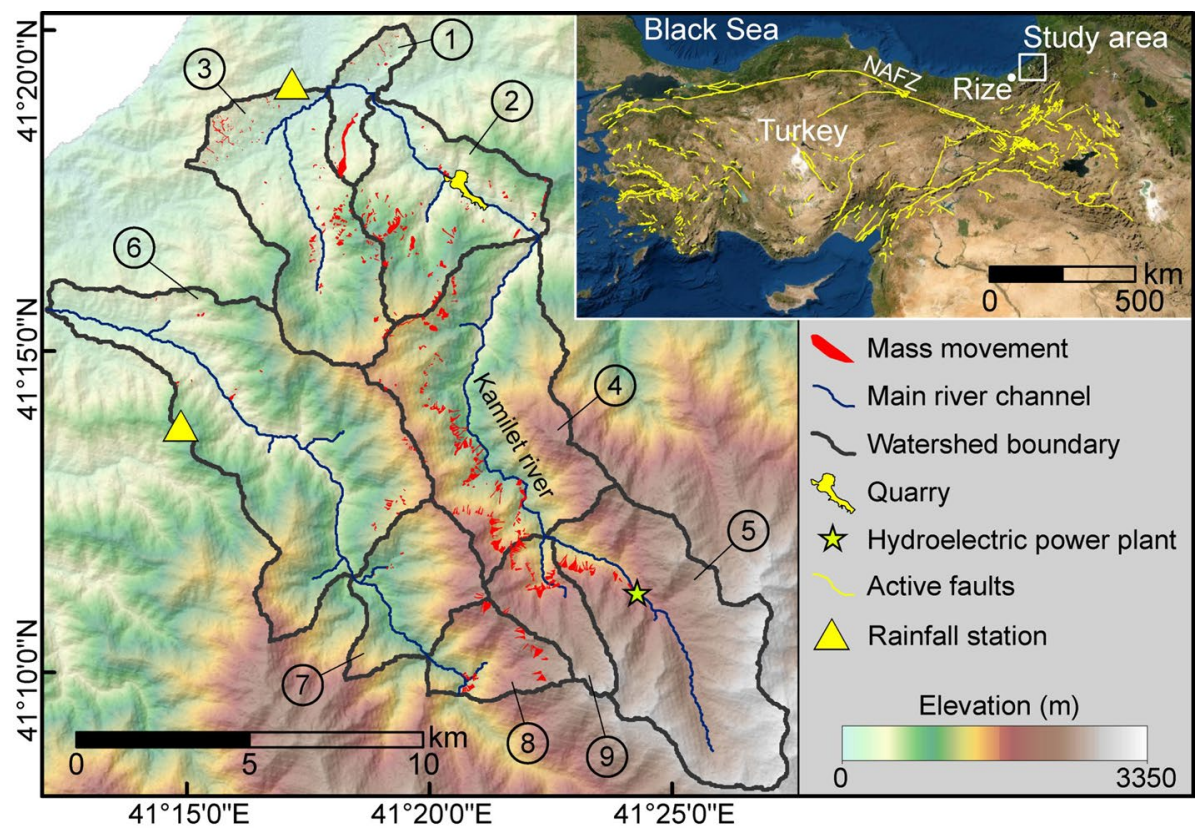

Fig. 1 Overview of the study area. The background areal image and DEM were taken from Google Earth and SRTM (NASA JPL 2013), respectively. Catchments are labeled by numbers. NAFZ: North Anatolian Fault Zone

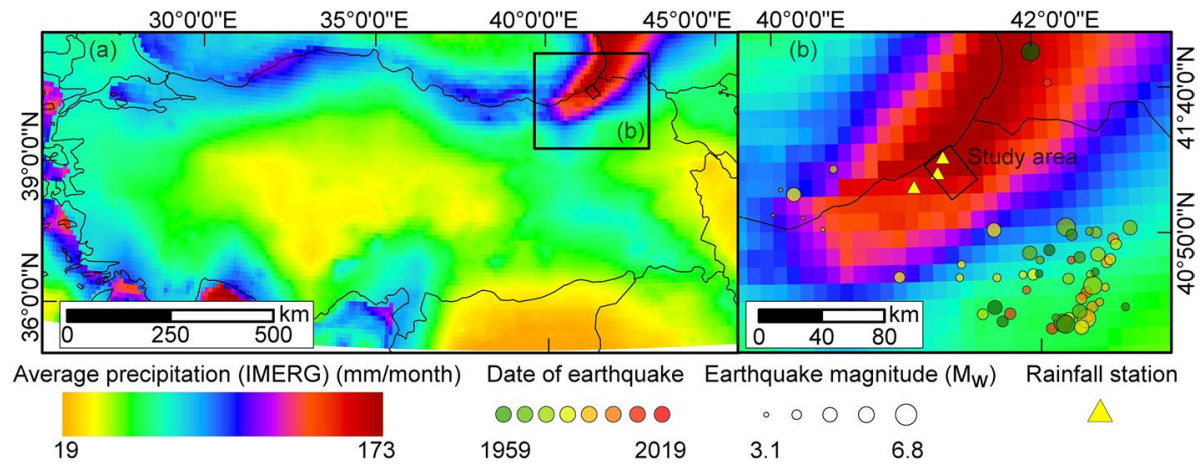

Fig. 2 Maps showing the characteristics of the study area regarding a the precipitation amounts that are the highest of entire Turkey (Huffman et al. 2019) and $\mathbf{b}$ the seismic record of the area for earthquakes that occurred after 1900 (U.S. Geological Survey 2017)

precipitation of strong events (i.e., above 0.95 quantile) is $30 \pm 1.5 \mathrm{~mm}$, whereas the maximum daily precipitation was received on September 24, 2017, as $176 \mathrm{~mm}$.

The study area extends approximately $25 \mathrm{~km}$ from the coastline and within the zone, elevation sharply increases to $3350 \mathrm{~m}$ from the sea level. This reflects the steep topography in the area. The maximum slope steepness within the examined area is $72^{\circ}$, whereas the average slope steepness is $29^{\circ} \pm 11^{\circ}$. 
As for the seismicity, the study area has not been exposed to strong external forces caused by earthquakes. The study area is approximately $270 \mathrm{~km}$ from the North Anatolian Fault Zone (Fig. 1). The Earthquake catalog of U.S. Geological Survey (2017) shows that in the last 100 years no earthquake $\left(M_{w}>3\right)$ occurred within a buffer zone of $50 \mathrm{~km}$ radius centered within the study area (Fig. 2b). The largest earthquake $\left(M_{w}=6.8\right)$ occurred in 1983, approximately $120 \mathrm{~km}$ southeast of the study area. Except for this event, only seven earthquakes of magnitude larger than 5.0 have occurred in the near vicinity and the closest epicentral location is $70 \mathrm{~km}$ away from the study area.

Although the site is not seismically active, landslides are one of the main natural hazards threatening the East Black Sea region and strong precipitation, land-use change and road construction are the most common factors causing landslides (Reis et al. 2009; Nefeslioglu et al. 2011; Raja et al. 2017). Based on the fatal landslide database of Turkey (Görüm and Fidan 2021), which includes 90-year landslide records, the majority of fatal landslide (55.5\%) occurred in the Black Sea. During the last decade, an increasing number of road construction projects have been elevating the landslide susceptibility in the Black Sea Region (Raja et al. 2017). In particular, within our study area, road constructions have a significant role in landslide occurrences (Akbulut and Kurdoglu 2015). Road construction has been conducted for three main reasons: (1) to increase the accessibility to highlands to boost tourism in the region (Green Road project, DOKAP 2014), (2) to build a hydroelectric power plant (HEPP) in the southern part of the study area and (3) to improve the road network overall. Some of the roads constructed under the third category could be indirectly associated with the first two classes because newly constructed roads may have further stimulated the construction of others.

Among these road constructions, in particular, the HEPP project has affected the natural course of erosional processes since 2016 (Fig. 3). Local interviews argue that explosives were used in some parts of the road construction to facilitate the progress of the HEPP project. This most likely weakened the shear strength of hillslope material, increasing the landslide susceptibility of the given site and promoting the failures. In fact, the local environmental organizations (Arhavi Doğa Koruma Platformu) provided evidence to this claim in an early 2020 report where an increased sediment content was noted in the Kamilet River (Fig. 3).

\section{Materials and method}

We map both mass movements and constructed roads from 2010 to June 2020. To create these multi-temporal inventories, we use PlanetScope (3-5 m), Rapid Eye (5 m) images acquired from Planet Labs (Planet Team 2017) and high-resolution Google Earth scenes. The details of the satellite images we used are presented in Table S1.

We create inventories based on the systematic examination of satellite images through manual mapping. We delineate mass movements as polygons and also assign a point to the crest of each polygon manually to identify some characteristics of them (i.e., slope and minimum distance of failed material to roads). We always compare two images to map mass movements that occurred and roads that were constructed within the examined time window. We do not follow a fixed temporal resolution to map mass movements or roads. In fact, we aim at using all the available cloud-free satellite images. Thus, the resulting temporal resolution of the inventories is not fixed and actually increases after 2016, following the increase in the number of available images. For instance, the temporal resolution of 

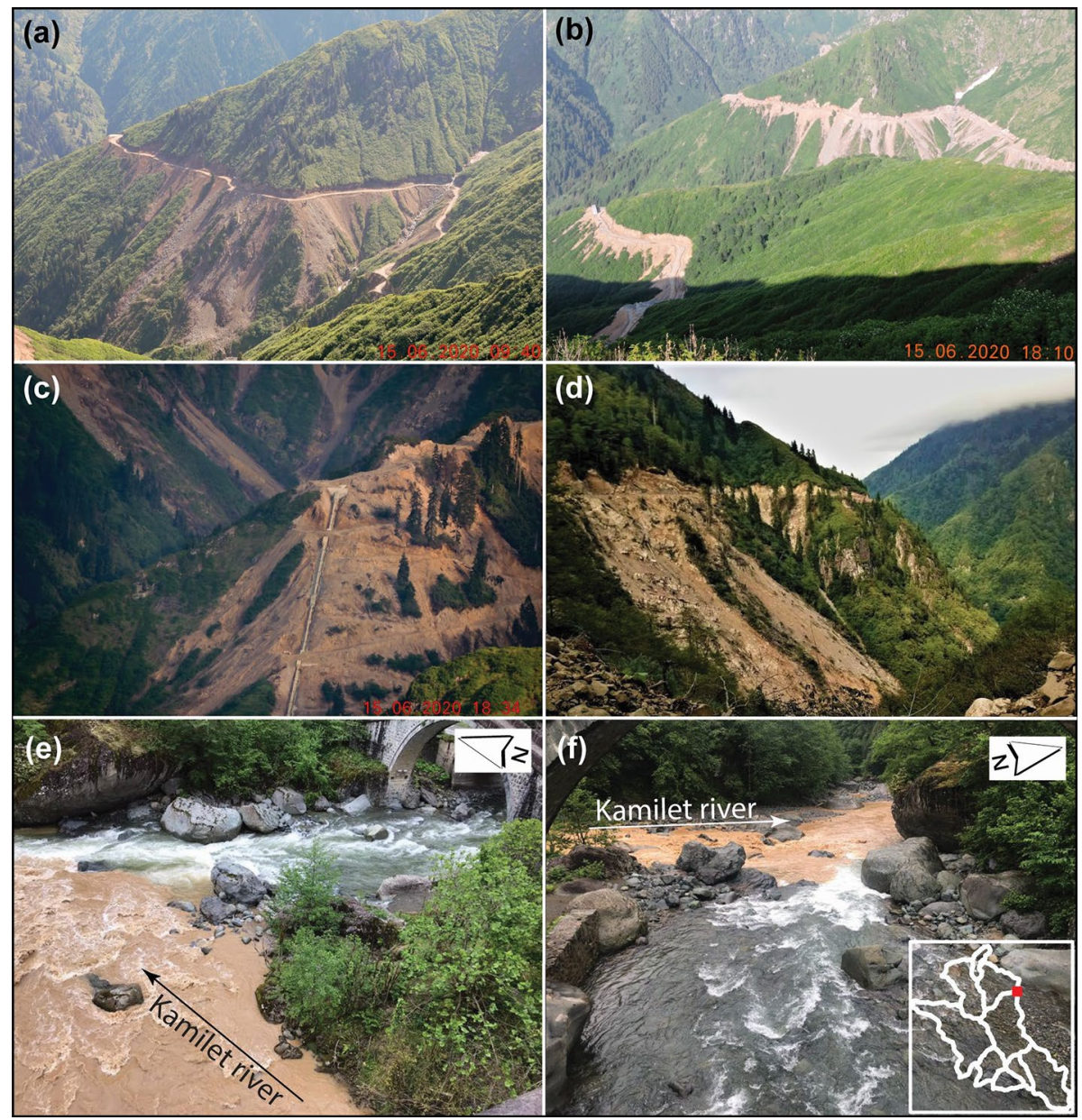

Fig. 3 Photographs showing $\mathbf{a}, \mathbf{b}, \mathbf{c}$ and $\mathbf{d}$ the mass movements on hillslopes associated with road constructions of HEPP (The photographs were taken on June 15, 2020) and (e and f) the intersection of Kamilet and Durguna Rivers ( $41^{\circ} 16^{\prime} 34^{\prime \prime} \mathrm{N}$ and $\left.41^{\circ} 22^{\prime} 32^{\prime \prime} \mathrm{E}\right)$ where increased sediment content in Kamilet River caused by the HEPP construction is evident (The pictures were taken in May 2020). The intersection location presented in panel $\mathbf{e}$ and $\mathbf{f}$ is given in the lower right of the panel $\mathbf{f}$ (Photographs by Hasan Sitkı Özkazanç)

our inventory is approximately one year between 2010 and 2011, whereas, after 2016, it is much finer at up to one-month frequency (Table S1).

While mapping, we examine whether or not mass movements are associated with road construction. For this binary labeling, we manually go through the inventory and identify the ones having contact with roads. If the target mass movement crosses a road or is initiated right under a road cut, we label the given mass movement as a human-induced one.

Overall, during the road construction project some of the excavated materials are dumped into the river channels. The differentiation between dumped materials and human-induced landslides is challenging. Regardless, these processes initiate additional anthropogenic sediment loads to river channels. Notably, the extra sediment load could cause river channel aggregation and that could lead to an increase in the probability and severity of flooding along the 
river channel (Fan et al. 2019). This indicates that both dumped materials and human-induced landslides appear as factors negatively affecting the natural sediment balance of a watershed and in this regard, they are equally hazardous. Therefore, in this study, we do not differentiate the dumped hillslope materials and landslides; instead, we consider them all as humaninduced mass movements.

Also, we group mass movements that occurred and roads that were constructed based on two different criteria, namely by assigning a label describing the purpose of road construction and the occurrence/construction time. For the former one, we examine the purpose of road constructions and categorize them under three headings: (1) HEPP project, (2) Green Road project and (3) others (i.e., roads constructed after 2010 for other reasons than Green road and HEPP projects). We make interviews with local people and make use of the information gathered from them to categorize roads. Using the same classification, we label not only roads but also the corresponding mass movements. We also compare mass movements associated with road constructions and the ones triggered by precipitation. We do so by examining the occurrences of mass movements for different catchments. This allows us to better investigate the anthropogenic influence by comparing two adjacent catchments exposed to different levels of external disturbances caused by road construction.

For the second criterion, we label mass movements/roads using one year of fixed temporal windows. As a result, we create 11 temporal categories that we can use to examine the evolution of both mass movements and roads from 2010 to June 2020 with one-year temporal resolution. If the existing mass movements expand over time, we only map the new surface in the examined time window.

To examine the landscape characteristics and precipitation regimes, we use Shuttle Radar Topography Mission (SRTM) digital elevation models (approximately 30-m resolution) (NASA JPL 2013), and the Global Precipitation Measurement (GPM), the Integrated MultiSatellite Retrievals (IMERG) Final Run product (Huffman et al. 2019) and rainfall data provided by the Turkish State Meteorological Service (TSMS 2020) for three stations located nearby the study area (Fig. 2b).

Ultimately, we compare our human-induced mass movement inventory with a sample of earthquake-induced landslide inventories, available via the U.S. Geological Survey ScienceBase platform (Schmitt et al. 2017; Tanyaş et al. 2017). We make this comparison to assess how hazardous road construction could be compared to naturally occurring landslides. For the comparison, we examine the landslides' size statistics, which has been used as a basis to identify landslide-event magnitude scale ( $\mathrm{mLS}$ ) and provides a measure to quantify the severity of landslide events (Malamud et al. 2004). We calculate mLS using the code provided by Tanyaş et al. (2018). We also calculate the slope of the power-law distribution ( $\beta$, power-law exponent) that the frequency-density distribution of landslides exhibits (Guzzetti et al. 2002; Malamud et al. 2004; Tanyaş et al. 2019) using the method proposed by Clauset et al. (2009). To estimate an earthquake magnitude for an equivalent earthquake-induced landslide inventory with our human-induced one, we use the empirical relation between earthquake magnitude (M) and landslide-event magnitude scale (Malamud et al. 2004).

$$
\mathrm{mLS}=1.29 \times M-5.65
$$




\section{Results}

\subsection{Mapping of roads and landslides}

We identified the roads associated with "HEPP" and "Green Road" projects (Fig. 4a)

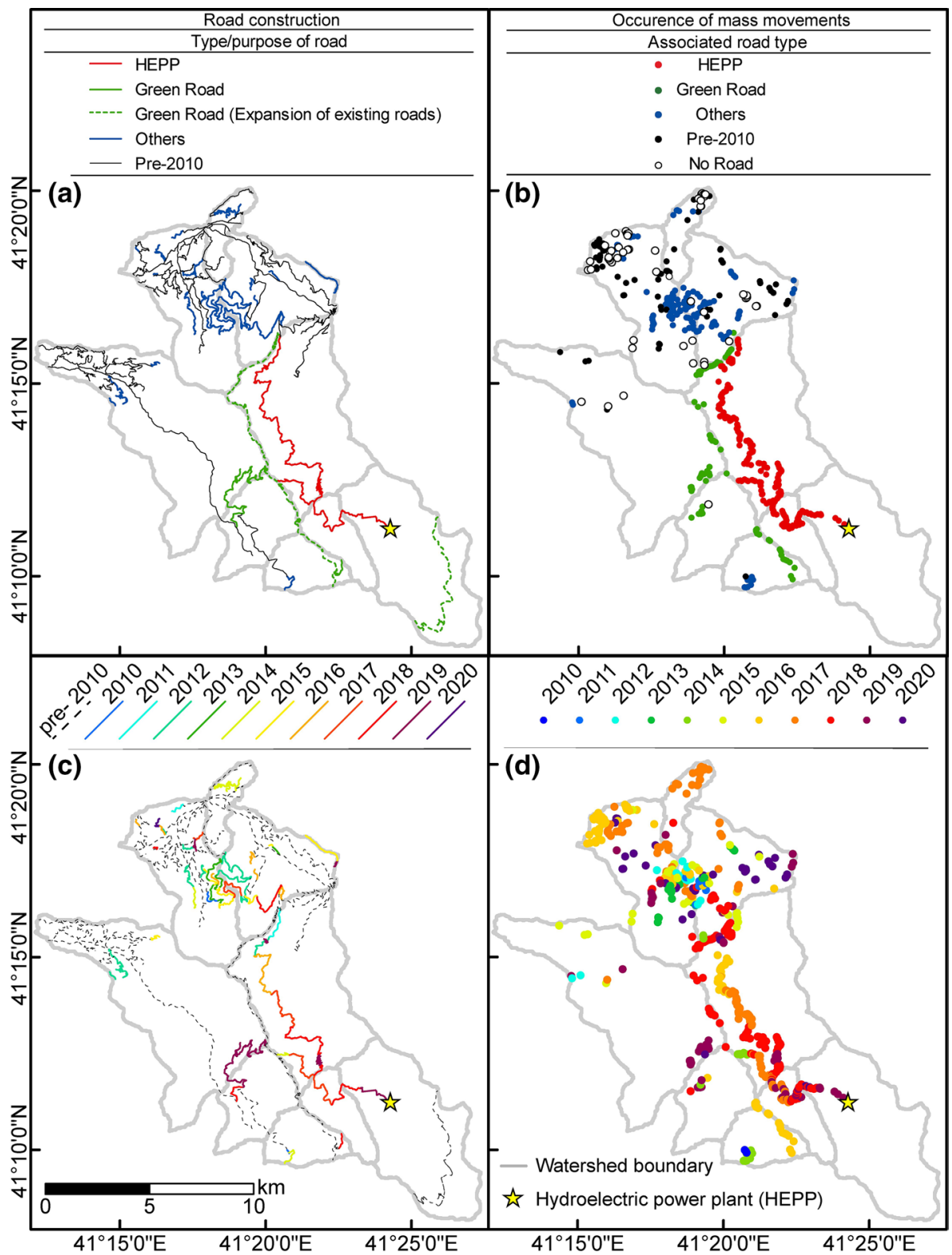

Fig. 4 Maps showing the distribution of $\mathbf{a}$ the roads constructed for different purposes and $\mathbf{b}$ the associated landslides as well as $\mathbf{c}$ the temporal evolution of the roads and $\mathbf{d}$ the associated landslides 
based on information from our local contacts and interviewees. They informed us about other expansion work conducted along the route of the Green Road project. We could not identify the time of these expansions, but we know the sections where the engineering work was carried out. We labeled the roads that already exist as of January 2010 as "Pre-2010" based on our analyses of satellite scenes. We labeled the rest of the roads constructed after 2010 as "Others." Based on the identified roads, we also mapped and labeled corresponding mass movements, which are mostly characterized by shallow, rotational slides (Fig. 4b).

To create these road and mass movement inventories, first, we mapped both roads and mass movements associated with HEPP (Fig. 4). Mapping mass movements was particularly challenging because of the short-term interactions between mass movements and engineering activities. Specifically, local people indicated that the excavated hillslope materials were mostly dumped into the river channels during the construction, and also down the slope of the road cut. This may have also induced some landslides further down the hillslope because of the additional load. Notably, this makes the identification of landslides difficult because the dumped hillslope materials and landslides triggered by the construction are mostly mixed and have a similar appearance in satellite scenes. For instance, Fig. 5a and $\mathrm{b}$ shows a segment of the road excavation conducted as part of the HEPP
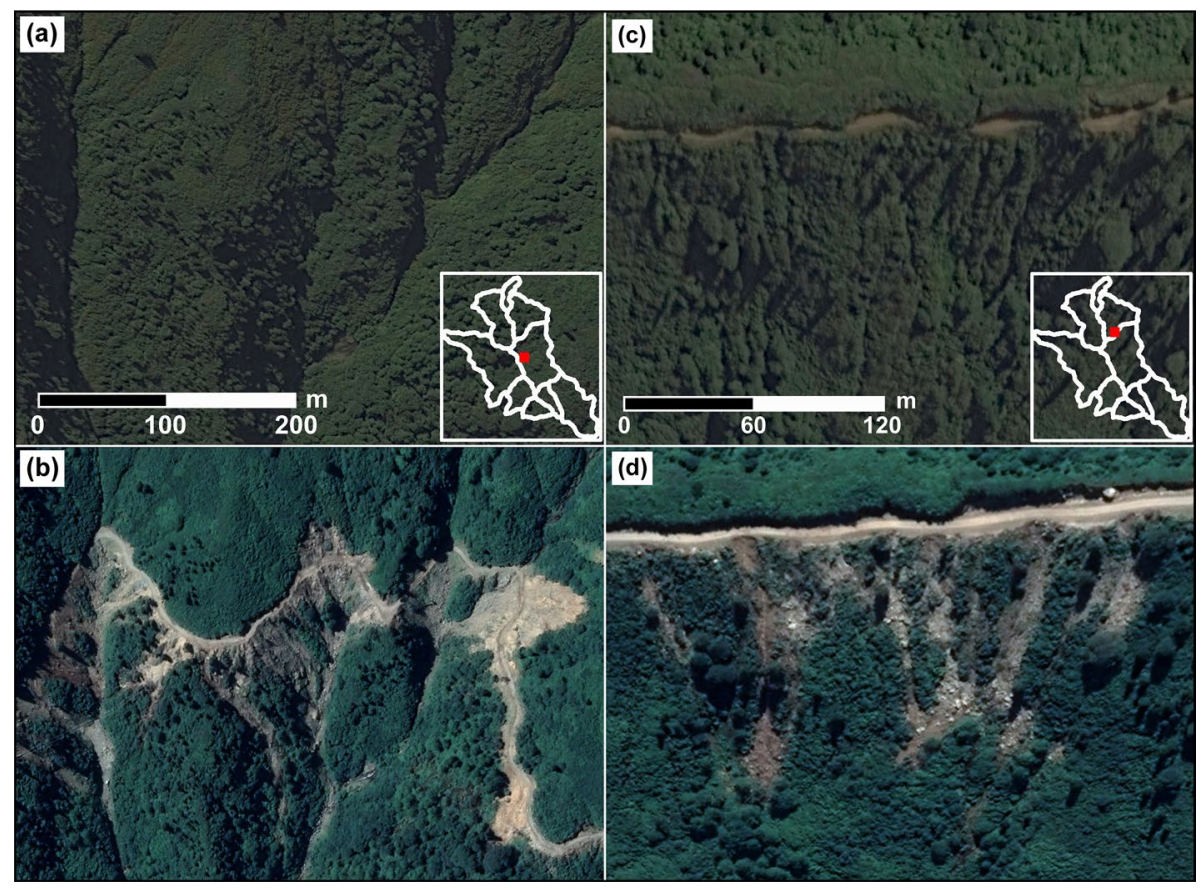

Fig. 5 Google Earth scenes showing the pre- and post-excavation landscape in a selected area (a-b) along the route excavated for the HEPP project $\left(41^{\circ} 13^{\prime} 56^{\prime \prime} \mathrm{N}\right.$ and $\left.41^{\circ} 20^{\prime} 18^{\prime \prime} \mathrm{E}\right)$. The examined segment of the road was constructed between July 17, 2016, and September 6, 2016. Within the same period, mass movements widely occurred. We also identified some mass movements enlarged between September 6, 2016, and July 9, 2017. Another pre- and post-images (c-d) showing mass movements at a selected site $\left(41^{\circ} 15^{\prime}\right.$ $37^{\prime \prime} \mathrm{N}$ and $\left.41^{\circ} 20^{\prime} 24^{\prime \prime} \mathrm{E}\right)$ along the route excavated for the Green Road project. Mass movements occurred between September 18, 2017, and May 27, 2018. The locations of these mass movements were given in the lower right of panel (a) and (c) 
project. This satellite image clearly shows that dumped materials are mixed with landslides triggered by road construction. We can both see mass movements that were initiated from the upper or lower hillslopes. For the former ones, we can be sure that these are humaninduced landslides. However, for the latter cases, we cannot differentiate whether they are solely dumped materials or human-induced landslides. In fact, most likely, their genesis is the result of the coupled effect of both processes. Therefore, as we also stressed in Sect. 3, we considered them all as human-induced mass movements as they are equally harmful as anthropogenic sediment sources.

We also mapped mass movements that occurred along with the Green Road project (Fig. 4a). Some of the mass movements occurred along existing roads, which were expanded in relation to the Green Road project. Similar to the HEPP case, dumped hillslope materials might also play a role in these mass movements. However, Fig. 5c and $\mathrm{d}$ shows that the crests of some mass movements extend backward from the road and therefore, we argue that there must be a mixture of both dumped materials and human-induced mass movements if they are not purely human-induced mass movements.

Moreover, we mapped mass movements that occurred along other roads (i.e., Others) that were excavated during the same period (Fig. 4 and Fig. S1). These are mostly secondary and private roads opened to access agricultural sites or houses and therefore, they were created without the use of explosives. Consequently, excavated materials are expected to be less compared to HEPP and Green Road, which were designed for higher traffic loads that require a wider road section and cut.

Ultimately, we mapped landslides that occurred along the existing roads (Pre-2010) (Fig. S2) and the ones triggered by natural agents irrespective of roads (No Road) (Fig. S3). Precipitation is the most likely triggering factor for these landslides. However, for the Pre-2010 case, road works should have played a crucial role in the failure mechanism by disturbing both resisting forces against sliding and hydrological conditions. As for the No Road case, in addition to precipitation as a triggering factor, some anthropogenic factors might have played a role, albeit to a much lesser extent. We will elaborate on the possible contribution of those indirect anthropogenic factors in Sect. 5.

\subsection{Analyses of mass movements}

We mapped 557 mass movements and a $267.2 \mathrm{~km}$ long road network. Overall, $33.9 \%$ of the roads were developed during the last 11 years, for various purposes (Tables 1 and 2). Among them, $10.8 \%$ is associated with the HEPP project and $4.4 \%$ is related to the Green

Table 1 Characteristics of different road types

\begin{tabular}{lllll}
\hline Type/purpose of road & & Length $(\mathrm{km})$ & $(\%)$ & $\begin{array}{l}\text { Average steepness of the terrain } \\
\text { that the road is crossing (degree) }\end{array}$ \\
\hline HEPP & $:$ & 28.8 & 10.8 & 33.0 \\
Green Road & $:$ & 11.9 & 4.4 & 26.0 \\
Green Road (Expansion of & $:$ & 30.6 & 11.4 & 22.0 \\
$\quad$ existing roads) & $:$ & 49.9 & 18.7 & 20.0 \\
Others & $:$ & 146.1 & 54.7 & 22.0 \\
Pre-2010 & $:$ & 267.2 & & \\
Total & &
\end{tabular}


Table 2 Characteristics of mass movements associated with different road types

\begin{tabular}{|c|c|c|c|c|c|c|c|c|}
\hline \multicolumn{2}{|c|}{$\begin{array}{l}\text { Associated road } \\
\text { type }\end{array}$} & Count & $(\%)$ & $\begin{array}{l}\text { Total } \\
\text { area } \\
\left(\mathrm{km}^{2}\right)\end{array}$ & $(\%)$ & $\begin{array}{l}\text { Aver- } \\
\text { age slope } \\
\text { (degree) }\end{array}$ & $\begin{array}{l}\text { Average } \\
\text { landslide size } \\
\left(\mathrm{m}^{2}\right)\end{array}$ & $\begin{array}{l}\text { Average minimum } \\
\text { distance of landslide to } \\
\text { road }(\mathrm{m})\end{array}$ \\
\hline HEPP & : & 196 & 35 & 1.3 & 51 & 34 & 6396 & 20 \\
\hline Green Road & $:$ & 75 & 13 & 0.3 & 13 & 31 & 4449 & 22 \\
\hline Others & $:$ & 148 & 27 & 0.5 & 21 & 29 & 3230 & 60 \\
\hline Pre-2010 & : & 83 & 15 & 0.2 & 6.1 & 24 & 1829 & 41 \\
\hline No Road & $:$ & 55 & 9.9 & 0.2 & 9.3 & 28 & 3453 & 65 \\
\hline Total & : & 557 & & 2.5 & & & & \\
\hline
\end{tabular}

Road project. Also, some of the existing roads have been extended in relation to the Green Road project and this contribution refers to $11.4 \%$ of all roads in the study area. Moreover, $18.7 \%$ of the roads constructed after 2010 are not directly associated with the HEPP nor the Green Road projects, but some indirect connections could exist (Others).

We also examined mass movements in relation to road work. Our findings show that $90.1 \%$ of them occurred after 2010 while being in immediate proximity to the roads (Table 2). As for the cumulative area of mass movements, the anthropogenic influence is also significant: $90.7 \%$ of total size is associated with road constructions. Roads constructed as part of the HEPP project have the most substantial contribution to mass movement occurrences. In the study area, $1.3 \mathrm{~km}^{2}$ of mass movements were solely caused by the HEPP project, which refers to $50.6 \%$ of the total size identified in the study area. During the last 11 years, $9.9 \%$ of mass movements occurred with no direct relationship with roads. In terms of total size, the influence of these mass movements constitutes $9.3 \%$ of the total area of mass movements.

This static summary is complemented below by examining the variation in both road construction and mass movement occurrence on a temporal basis (Figs. 4c, d and 6). For instance, we noticed a peak value in road construction in 2012 (Fig. 6a). However, the peak in the constructions does not correspond to a significant number of mass movements. This is mainly because of the morphologic conditions encountered through the route. In fact, most of the roads we mapped between 2011 and 2012 are associated with roads categorized as Others (Fig. 6b). The mean slope steepness observed through these roads is $20^{\circ}$, which is the lowest steepness of the terrain that the road is crossing among different construction projects (Table 1). The highest slope steepness is observed through the roads associated with the HEPP project $\left(33^{\circ}\right)$, whereas the two other categories (i.e., Pre-2010 and Green Road) both cross relatively smooth topography compared to the HEPP project (Table 1). Specifically, the Green Road project mainly follows the existing old road path, which passes through ridges. Therefore, a predominant part of these roads did not require any hillslope cut in our study area. This explains why the mass movements triggered in response to the activities of the HEPP project gave the largest damage among different construction projects (Table 2).

Figure $6 \mathrm{a}$ also shows that the total length of constructed roads per year continuously increases between 2013 and 2019. However, the increase in the number of mass movements associated with road construction does not follow the same trend with the road constructions. The largest mass movement rates are observed between 2015 and 2019 and this refers to the period that the $H E P P$ project-related road constructions were carried out. Therefore, as we stressed above, the. 


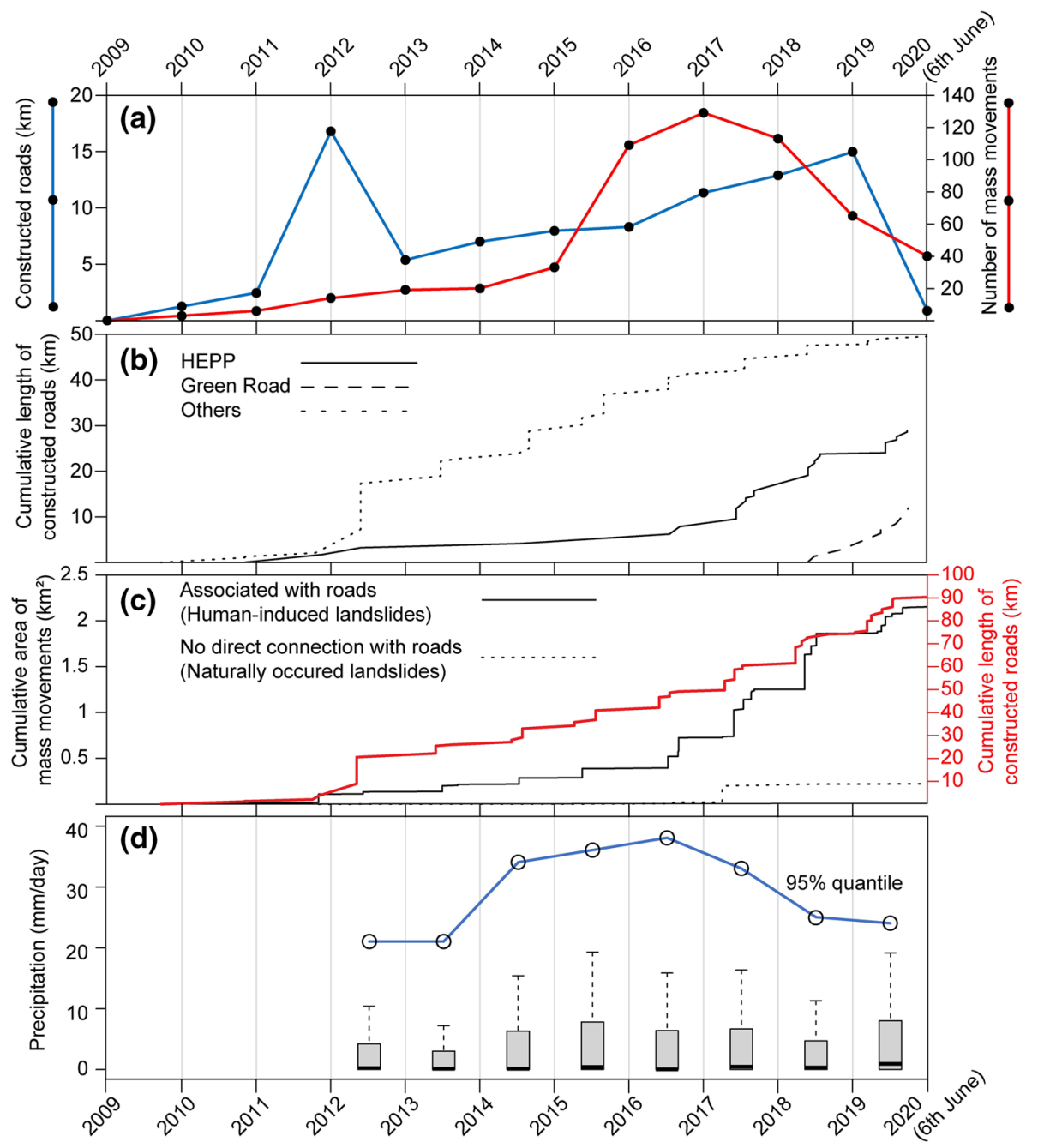

Fig. 6 Plots showing the yearly variation in road constructions and mass movement occurrences from 2010 to 2020 in terms of a the number of mass movements against the entire length of constructed roads, b the roads constructed for different purposes, $\mathbf{c}$ the cumulative trend in total mass movement size and road length and $\mathbf{d}$ the variation in rainfall regime expressed by precipitation amounts above the 0.95 quantile and boxplots excluding outliers. Precipitation data gathered from the rainfall stations (TSMS, 2020) are available from 2012 onward

steepness of the terrain, which is quite steep along the route of the HEPP project, also plays a major role in these observations.

The increase in the mass movement trend could also be linked to strong precipitation (Fig. 6d). For instance, between 2015 and 2018 where high mass movement rates exist, the study area was exposed to the strongest rainfall events of the examined period. However, the precipitation component does not solely explain the variation in mass movement rates. For instance, in 2014, mass movement rate is significantly lower than 2017 level, although the amount of precipitation is quite similar to 2017 level (Fig. 6d). 
The findings presented above imply that the road construction is the main factor governing mass movement rates and precipitation could be considered as a predisposing factor elevating its susceptibility. To elaborate on this issue, we examined the spatial distribution of mass movements and the variation in the total mass movement population in relation to distance to roads (Fig. 7). Our findings show that $88 \%$ of the total mass movement population occurred within a zone bounded by a $100 \mathrm{~m}$ road-buffer zone. This confirms that the increase in mass movement rate is mostly due to road constructions.

We also examined how the road constructions evolved after 2010 in each catchment and, consequently, how this affected the occurrences of mass movements per hydrological unit. Figure 8 shows the summary of these temporal evolutions. For this analysis, we excluded the naturally occurring landslides. Our findings show that if there is no significant road construction, the number of mass movements is relatively low. For instance, catchments 1, 2, 3 and 4 are adjacent catchments. Among them, catchment 1 is the only hydrological unit where the total length of constructed roads in the last 11 years is less than $5 \mathrm{~km}$. The associated total mass movement size in catchment 1 is $0.02 \mathrm{~km}^{2}$, whereas, in the three other catchments (2, 3 and 4), it ranges from 0.24 to $0.82 \mathrm{~km}^{2}$. We observed a similar
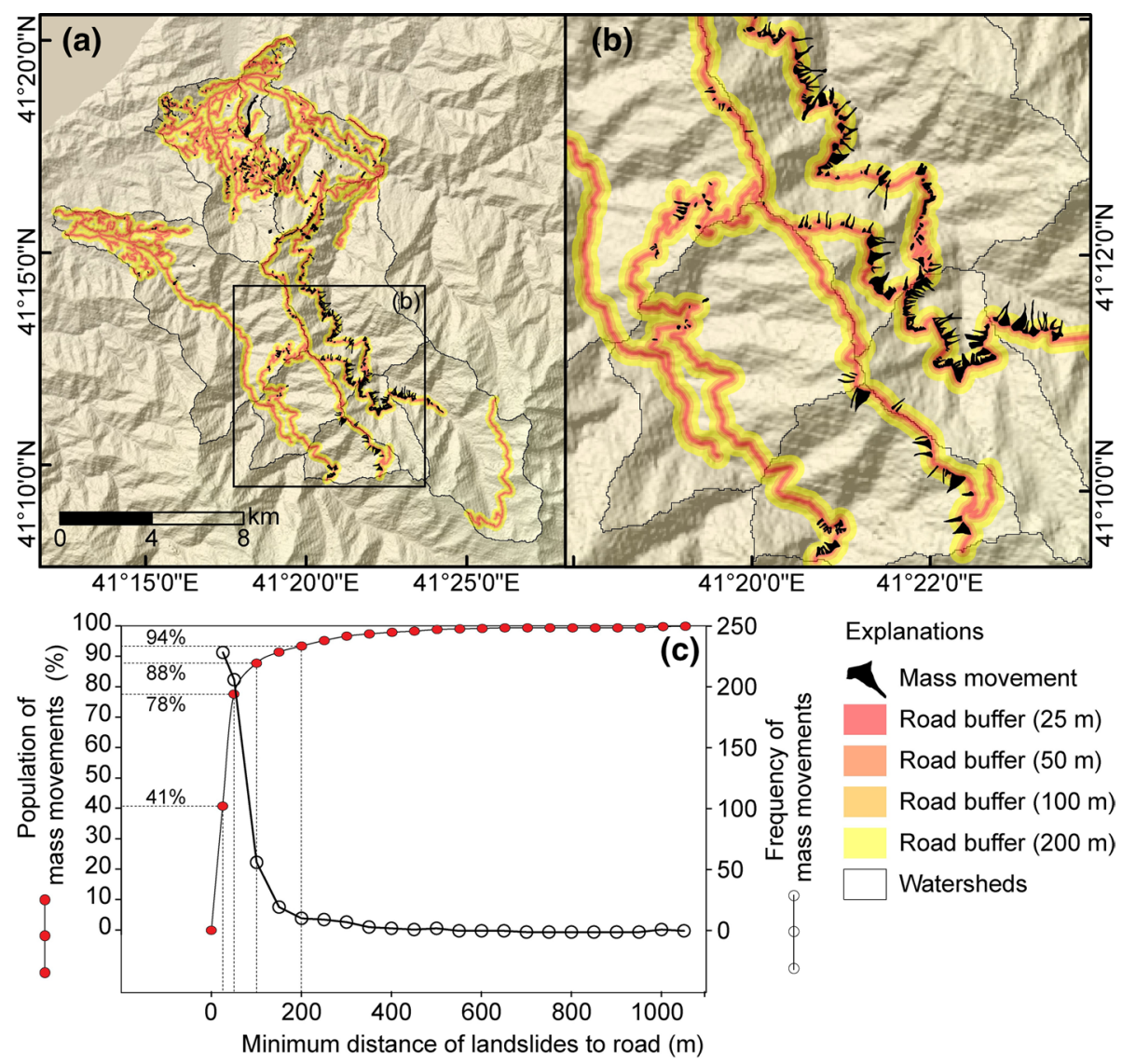

Fig. 7 Plots showing a the areal extent of the examined area and spatial distribution of mass movements with respect to road buffer zones, $\mathbf{b}$ a closer view of mass movements and buffer zones and $\mathbf{c}$ variation in mass movement population and frequency of mass movements in relation to distance to roads 

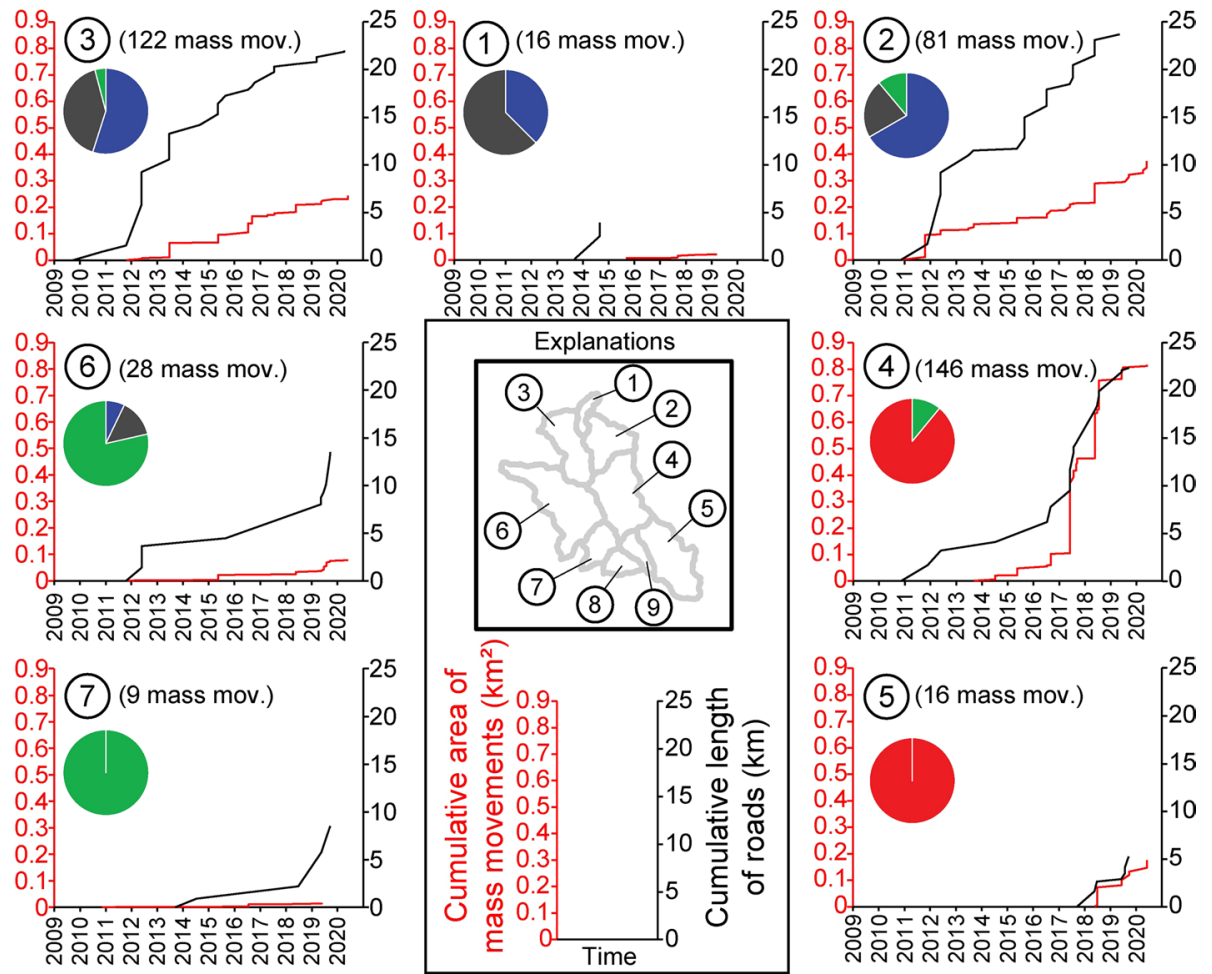

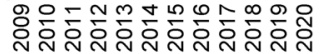
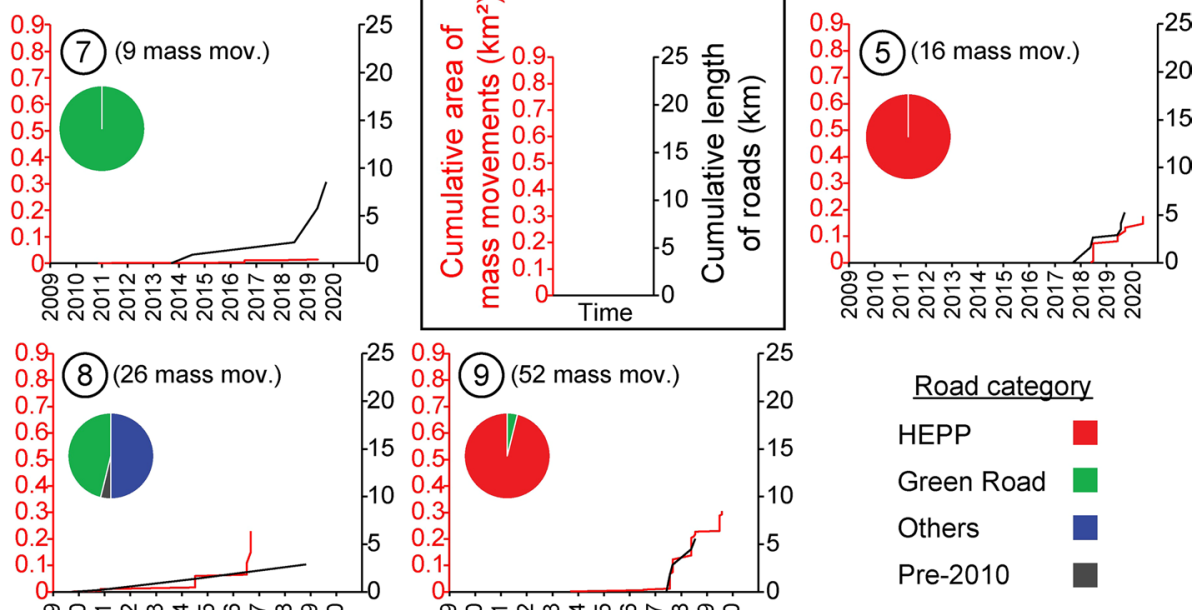

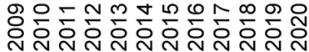

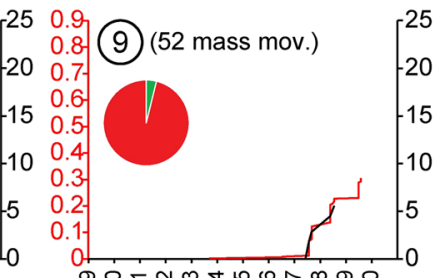

\section{Road category}

HEPP

Green Road

Others

Pre-2010

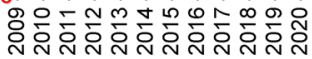

Fig. 8 Figure showing the temporal evolution of both roads and mass movements within each catchment from 2010 to June 2020. Catchments 2, 3 and 4 appear as hydrological units exposed to the highest road construction and consequently, the largest number of mass movements

situation in catchments 5,8 and 9, where we identified a relatively low amount of road constructions $(<\sim 5 \mathrm{~km})$ associated with a limited number of mass movements (Fig. 8). In catchments 6 and 7, the total length of the road $(\sim 10 \mathrm{~km})$ is in between two other sets we mentioned above, but we identified 28 and 9 mass movements in these catchments. These roads are mostly associated with the Green Road project and thus the limited number of mass movements is most likely because of the steepness of the topography along the route followed during the construction (Table 1).

We also compared human-induced mass movements with naturally occurred ones in terms of slope steepness and size of mass movements. Figure 9 shows that slope steepness of human-induced mass movements varies quite broadly compared to naturally occurred landslides. Hillslopes where the slope steepness ranges from $15^{\circ}$ to $50^{\circ}$ are associated with a minimum of 20 and a maximum of 100 human-induced mass 


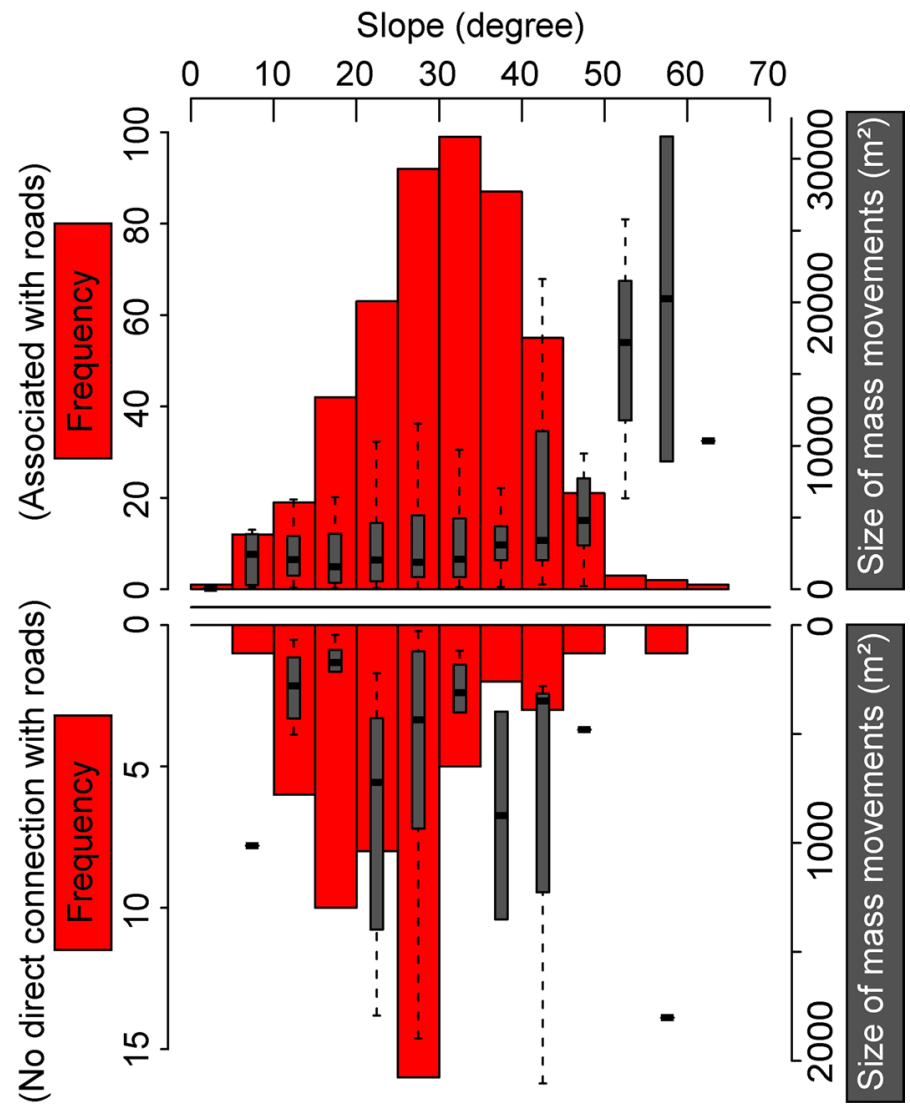

Fig. 9 The comparison of human-induced mass movements (top panel) with naturally occurring (bottom panel) ones in terms of slope steepness and mass movement size characteristics

movements. Conversely, the frequency of naturally occurring landslides increases up to $30^{\circ}$ (with a minimum of five and a maximum of 15 landslides), and then sharply decreases for steeper slopes. This large difference is undoubtedly induced by road excavations performed on steep slopes, as demonstrated by the much more numerous mass movements that occurred under anthropic disturbance. In fact, the same slope ranges appear to be mostly stable under natural conditions. Also, there is a large difference in average mass movement size triggered by road constructions and natural agents. The average size of human-induced mass movements is approximately $\sim 20,000 \mathrm{~m}^{2}$ in the steepest slopes (i.e., $55^{\circ}-60^{\circ}$ ), whereas the maximum average size of naturally occurring landslides is $\sim 1000 \mathrm{~m}^{2}$.

To assess the consequences of human effects on mass movements, we also compared our mass movement inventory (i.e., only the mass movements associated with road constructions) with nine earthquake-induced landslide-event inventories sharing similar landslideevent magnitude and total mass movement area. Figure 10 shows that the human-induced mass movement inventory we mapped is compatible with landslide events triggered by earthquakes having magnitudes varying from $M_{w}=5.9$ to $M_{w}=7.2$. This observation is made regardless of climatic and morphologic conditions. 


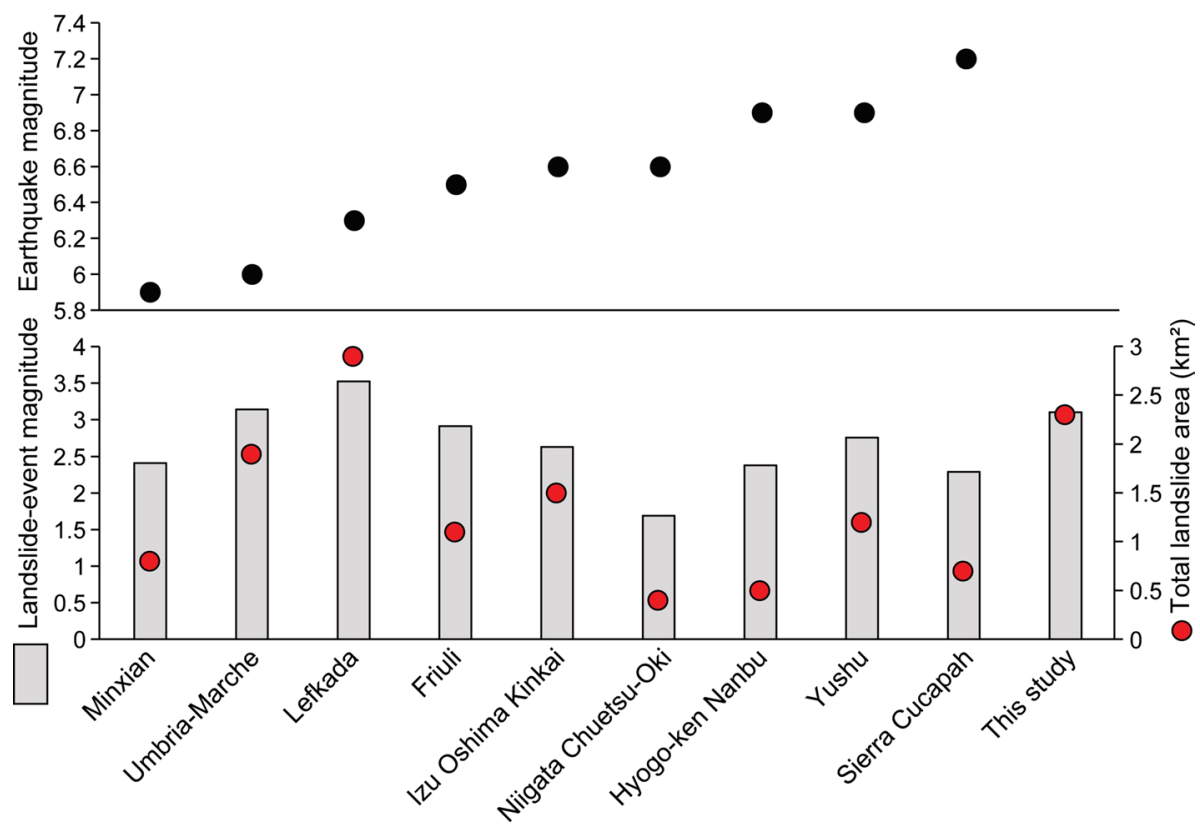

Fig. 10 Comparison between our human-induced mass movement inventory and nine earthquake-induced landslide inventories. Landslide-event magnitudes were calculated based on Tanyaş et al. (2018)

Among the ten examined cases, the total surface affected by landslides changes significantly from one case to another, with many cases showing a much larger spatial extent compared to our study site. Therefore, for a better comparison, we further investigated the landslide inventory associated with the 2013 Minxian earthquake $\left(M_{s}=6.6\right.$ based on the China Earthquake Network Center and $M_{w}=5.9$, according to USGS), where the extent of the region affected by landslides is equivalent to our study area. Specifically, the earthquake occurred between Minxian and Zhangixan (in the Gansu Province, China) on a thrust fault and triggered 2330 co-seismic landslides covering $200 \mathrm{~km}^{2}$ (Xu et al. 2014), which is also compatible with our study area where the examined catchments cover approximately $195 \mathrm{~km}^{2}$.

The cumulated extent of all the landslide polygons associated with the Minxian earthquake is $0.8 \mathrm{~km}^{2}$, whereas the total size of our human-induced mass movements is $2.3 \mathrm{~km}^{2}$. This shows that even the mass movements solely related to the HEPP project (total mass movement area is $1.3 \mathrm{~km}^{2}$ ) can significantly surpass the total co-seismic landslide size induced by the Minxian earthquake.

Before comparing the two inventories in terms of their size statistics, we first analyzed in terms of climatic and morphologic conditions. To collate the climatic information, we used the 20 years (from 2000-06-01 to 2020-03-31) precipitation time series accessed via the IMERG Final Run product, for both sites. Figure 11a shows that both sites have similar precipitation regimes, although the precipitation is relatively higher in our study area. Also, slope and local relief (derived from the SRTM DEM at $30 \mathrm{~m}$ ) observed in our study area indicate rougher terrain within the landslide-affected area compared to those affected by the Minxian earthquake (Fig. 11b and c) 

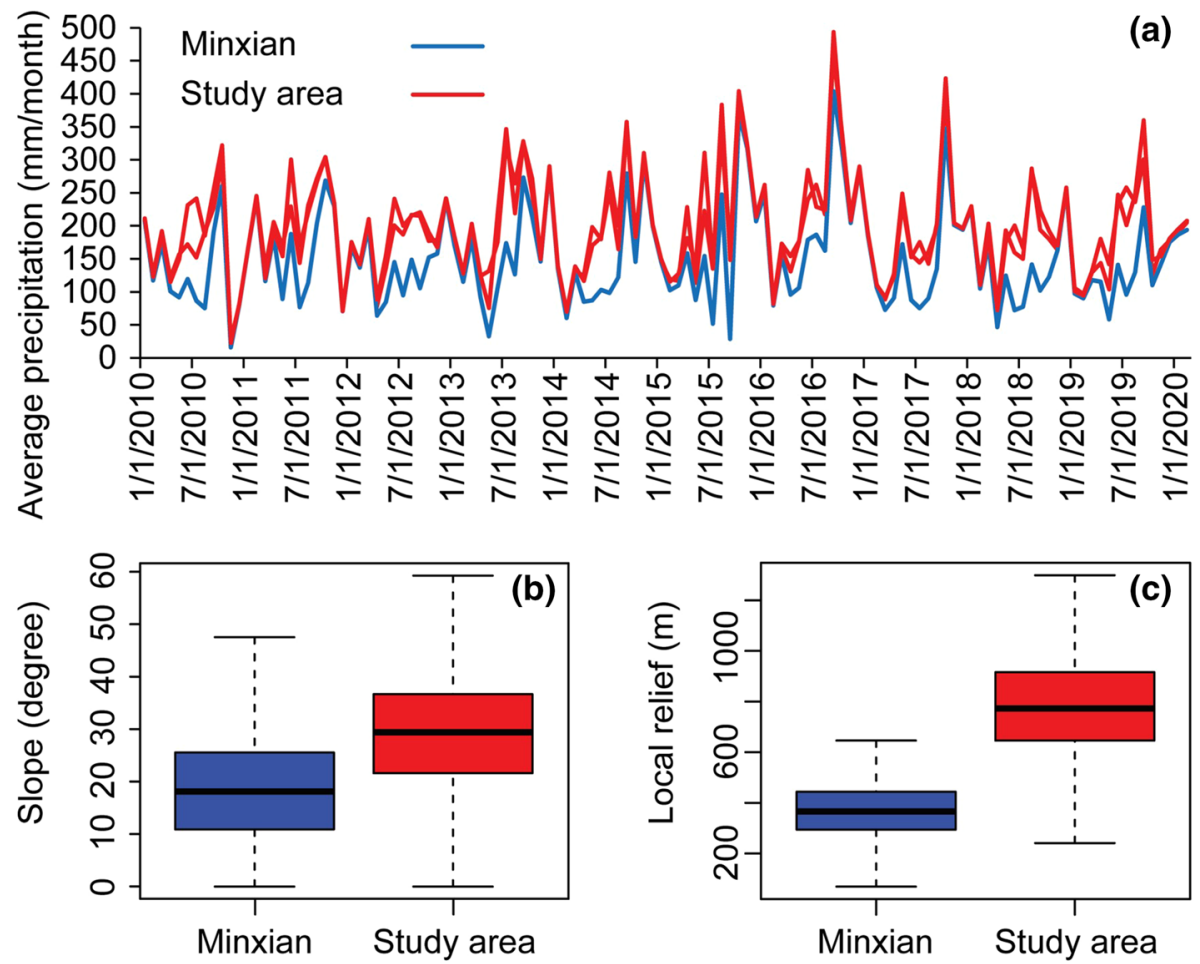

Fig. 11 Plots comparing our study area with the landslide affected area of 2013 Minxian earthquake regarding a precipitation amounts, $\mathbf{b}$ slope steepness and $\mathbf{c}$ local relief

We recognize that the two different sites cannot be thoroughly compared, because a much more thorough assessment should be made accounting for detailed geological, geotechnical and hydrological data. However, on the basis of the simplified overview we provide, we can hypothesize that if an earthquake with comparable magnitude to Minxian would occur in our study area, the resultant landslide event should be more significant because our study area is associated with higher precipitation and steeper terrain conditions.

The comparison between the probability- and frequency-area distributions of the human-induced mass movements we mapped and those naturally triggered by the 2013 Minxian earthquake shows that larger mass movements were triggered in our Turkish site (Fig. 12). The power-law exponents calculated for both our inventory $(\beta=-2.7)$ and the Minxian inventory $(\beta=-2.3)$ are close to each other and align well with distributions documented in the literature. Power-law exponents of naturally occurred landslide inventories fall in the range 1.4-3.4, with a central tendency 2.3-2.5 (Van Den Eeckhaut et al. 2007; Stark and Guzzetti 2009; Tanyaş et al. 2018).

We also calculated the magnitudes of our human-induced mass movement inventory $(\mathrm{mLS}=3.1)$ and the Minxian inventory $(\mathrm{mLS}=2.4)$. The difference between the two cases is consistent with our initial assumption that if a similar earthquake occurred in our study area, it would be more hazardous. In fact, based on the empirical relation between earthquake magnitude (M) and landslide-event magnitude scale proposed by Malamud et al. 

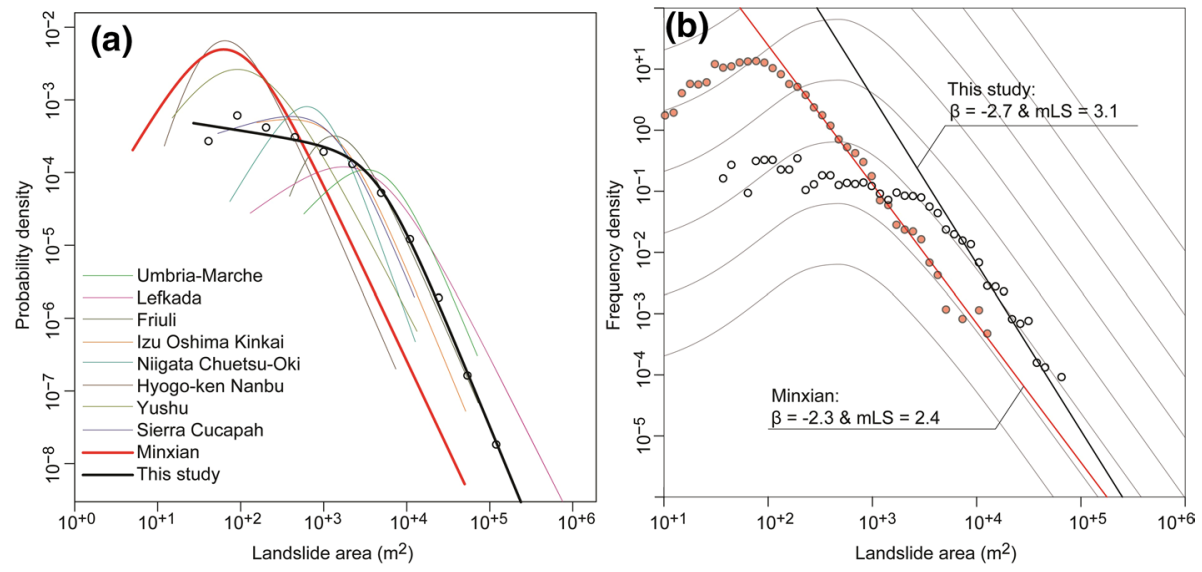

Fig. 12 Plots showing a the probability-area and $\mathbf{b}$ frequency-area distributions of selected landslide inventories as well as the mass movements associated with roads in our study area. The probability density curves presented in the panel (a) are fitted by a double-Pareto distribution using the code of Rossi et al. (2012). Power-law exponents $(\beta)$ were calculated based on the method proposed by Clauset et al. (2009), whereas power-law fits and landslide-event magnitudes were identified based on Tanyaş et al. (2018)

(2004), the earthquake magnitude for an equivalent earthquake-induced landslide inventory would be 6.8. This shows how destructive the anthropogenic effect on geomorphological processes could be compared to natural processes. The destruction caused by the sediment supply produced by the road constructions conducted in the last 11 years is compatible with the possible effect of a theoretical earthquake with a magnitude greater than 6.0.

\section{Discussion}

In this study, we provide quantitative, thorough systematically mapping mass movement rate after major road constructions in a mountainous region that is exposed to strong precipitation regimes. We specifically chose this region because seismicity does not play an active role here and therefore, capturing the anthropogenic effect on slope stability is more evident than in tectonically active mountainous regions such as Nepal, India or Pakistan. In tectonically active areas, the legacy of previous earthquakes could last for a long period, increasing the landslide susceptibility (Parker et al. 2015). In particular, after strong earthquakes, the elevated susceptibility is noticeable in the following years (up to nine years) and it decreases over time (Fan et al. 2018). Consequently, in such environments, it would be challenging to decompose the signal of earthquake legacy from anthropic disturbances. Precipitation could also add another layer of complexity. In fact, the occurrence of a landslide or a population of landslides is always controlled by multiple predisposing and triggering factors (e.g., geotechnical properties, hydrologic conditions, land cover, external loads, etc.) (e.g., Jaboyedoff et al. 2018). Capturing the relative contribution of each conditional factor requires not only highly detailed temporal landslide inventories-where we can assess the exact date of occurrence of each landslide- but also quantitative measurements of the predisposing factors at a given time. Notably, we lack such detailed datasets in this paper, and this is often the case in many landslide susceptibility studies, even when multi-temporal models are built (e.g., Guzzetti et al. 2005). 
Despite the complexity we faced and the limited temporal information on other controlling factors, we could still investigate whether a relationship exists between slope failures and anthropogenic effects. To address this issue, we made a binary classification distinguishing human-induced and naturally occurring mass movements on the basis of satellite images. However, in some cases, this identification was challenging, as well. For instance, the largest landslide we mapped within the region occurred on November 7, 2016, following a strong precipitation event (Ersoy 2017). This event was a shallow earth-slide flow that affected an area of approximately $0.2 \mathrm{~km}^{2}$ within the Kireçli village (Fig. 13). Satellite images show that the crest of the landslides is precisely aligned with an existing road. Some parts of the road failed as a result of this landslide (Ersoy 2017). The complexity in the interpretation arose because this landslide could also be linked to natural landscape evolution processes. In fact, the landslide initiated at the ridge of the slope where the susceptibility is generally higher. Thus, the shallow landslide might have been triggered regardless of the possible influence of the road.

In such cases, we labeled mass movements as naturally occurring ones since we do not have adequate support to argue that they are human-induced. We did this to implement a conservative approach in our analyses. However, emphasis should still be given to the possible direct or indirect anthropogenic effects. In fact, the road could have a direct implication by increasing the pore water pressure at the crest of the landslide. Also, the external loads associated with traffic might be another likely contributor to the landslide initiation. This event is a very interesting example also because of the existence of an active rock quarry approximately $3 \mathrm{~km}$ east. There, to dig into the slope and collect the material explosives are commonly used. Our local contacts informed us that some damages had been observed at houses in villages close to the quarry (i.e., Dikyamaç, Güneşli, Dereüstü villages). Among them, the Dereüstü village is located approximately $2.5 \mathrm{~km}$ northwest of the quarry, at a comparable distance to the mudflow location (Fig. 13). Therefore, the disturbance exerted by activities related to the quarry might have also played a role in triggering the landslide mentioned above.

A similar anthropogenic effect, if not even stronger, could also be valid for mass movements triggered along the roads constructed as part of the HEPP project, because of the explosives directly used to cut the hillslope. In fact, apart from hillslope cuts, explosives have been used in the last segment of the road approaching the HEPP site. In this section, approximately $620 \mathrm{~m}$ of the route passes through a tunnel. In such steep terrain, any time a new road is constructed, the damage to the slope is almost inevitable unless extreme precautions are taken. This is also reported in the literature. For instance, Froude and Petley (2018) report that from 2004 to 2016, 30\% and 43\% of fatal landslides occurred in India and Nepal are associated with road constructions. In these cases, the high landslide rates are not due to the lack of engineering solutions. In fact, landslides triggered in response to road construction projects are a well-known issue for both India and Nepal. The required and appropriate engineering practices necessary to minimize environmental damage have already been documented (e.g., Hearn and Shakya, 2017). The observed landslide hazard associated with road construction is mostly due to neglected engineering solutions (Hearn and Shakya 2017). Therefore, road construction in mountainous regions should not be envisioned unless the required investment in road design is available (Valdiya 2014; Hearn and Shakya 2017). Notably, the site we examined is a good example where road construction has widely damaged the landscape, and it is clear that better precaution or stabilization investments should have been put into practice. 


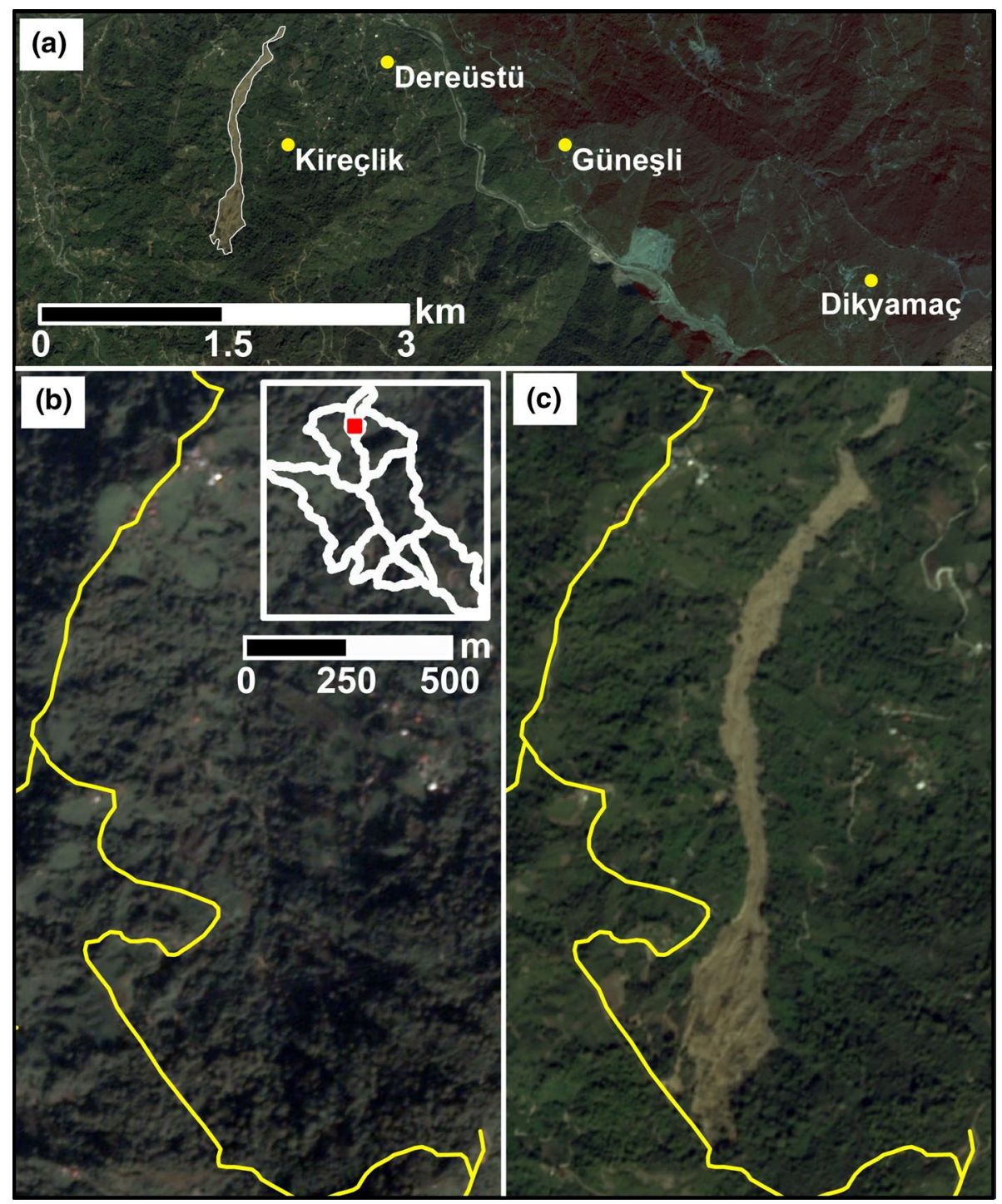

Fig. 13 PlanetScope scenes showing the pre- and post-landslide landscape of the largest landslide mapped within the study area $\left(41^{\circ} 17^{\prime} 37^{\prime \prime} \mathrm{N}\right.$ and $\left.41^{\circ} 18^{\prime} 27^{\prime \prime} \mathrm{E}\right)$. This landslide occurred on November 7,2016 . The location with respect to our study area is given in the upper right of the panel (b). Yellow lines in the panel (b) and $\mathbf{c}$ indicate roads

\section{Conclusions}

In this study, we report a distinct correlation of mass movements and major road constructions that explicitly shows human impact on mountainous environments which are under anthropogenic disturbance recently. Our results further suggest that slope instabilities increased drastically after major service road constructions for hydroelectric power plants and as well as other road extension works. Despite the high precipitation amounts 
in the region, naturally occurring landslides represent a minor percentage both in number and landslide-size-characteristics when compared to the equivalent human-induced mass movements. Regardless of the natural hillslope processes at play, the poor implementation of engineering practices able to ensure stable slope conditions in co- and post-construction phases not only resulted in dangerous widespread mass movements but also caused a substantial change in the sediment transport along with the river network. We could not access enough information on the potential effects of this to quantify increases in sediment loads. However, in the long term, the coarse nature of the material removed from the slopes could also clog narrow river passages, potentially damming small sections of the river network and could cause river-channel aggradation leading to flooding. Therefore, these extra sediments originating from human-induced mass movements could further induce a chain of hazardous events, which could affect not only people living nearby but also the rich biodiversity of the region that needs to be protected. This actually means that all endemic-rare plant and animal species that exist in Kamilet Valley are in danger now because of the poor engineering practice. Specifically for our study area, the results of this work emphasize the need to consider erosion and post-changes in hillslope processes and sediment flux that further lead to additional threats to the local community and biodiversity in response to poor engineering practices and any other anthropogenic disturbances.

We also stress that the impact of road construction can disturb the natural slope equilibrium to an extent comparable with moderate (larger than $6 M_{w}$ ) earthquakes. For a seismically inactive area as we examine, this observation is crucial to understand how hazardous the anthropogenic effects could be in terms of landsliding. Such an observation implies that human activities can have a large, if not even dominant, impact on landscape evolution and the natural regime of surface processes. This is part of the definition of "Anthropocene," an age where our society shapes nature for our purposes, frequently at the risk of damaging ourselves.

Supplementary Information The online version contains supplementary material available at https://doi. org/10.1007/s11069-021-05199-2.

Acknowledgements We are very grateful to HSÖ, an environmental activist from ADK Platformu, for providing us with valuable information regarding the road constructions and their consequences on the site.

Funding The research presented in this article is partially supported by King Abdullah University of Science and Technology (KAUST) in Thuwal, Saudi Arabia, Grant URF/1/4338-01-01.

\section{Declarations}

Conflict of interest The authors declare that they have no conflict of interest.

Data availability Co-seismic landslide inventories we examined are available from Schmitt et al. (2017) (https://www.sciencebase.gov/catalog/item/583f4114e4b04fc80e3c4a1a).

Open Access This article is licensed under a Creative Commons Attribution 4.0 International License, which permits use, sharing, adaptation, distribution and reproduction in any medium or format, as long as you give appropriate credit to the original author(s) and the source, provide a link to the Creative Commons licence, and indicate if changes were made. The images or other third party material in this article are included in the article's Creative Commons licence, unless indicated otherwise in a credit line to the material. If material is not included in the article's Creative Commons licence and your intended use is not permitted by statutory regulation or exceeds the permitted use, you will need to obtain permission directly from the copyright holder. To view a copy of this licence, visit http://creativecommons.org/licenses/by/4.0/. 


\section{References}

Acker JG, Leptoukh G (2007) Online analysis enhances use of NASA earth science data. Eos Trans Am Geophys Union 88:14-17

Akbulut S, Kurdoglu O (2015) Türkiye'de acil ve öncelikle korunmasi gereken bir alan: Kamilet ve Durguna Vadileri (Arhavi) ve koruma gerekçeleri. Kastamonu Üniversitesi Orman Fakültesi Derg 15:279_ 296 (in Turkish)

Alan I, Balci V, Keskin H et al (2019) Tectonostratigraphic characteristics of the area between Çayeli (Rize) and Ispir (Erzurum). Maden Tetk Ve Aram Derg 158:1-29

Atta-ur-Rahman KAN, Collins AE, Qazi F (2011) Causes and extent of environmental impacts of landslide hazard in the Himalayan region: a case study of Murree, Pakistan. Nat Hazards 57:413-434. https://doi.org/10.1007/s11069-010-9621-7

Barnard PL, Owen LA, Sharma MC, Finkel RC (2001) Natural and human-induced landsliding in the Garhwal Himalaya of northern India. Geomorphology 40:21-35. https://doi.org/10.1016/S0169555X(01)00035-6

Brown AG, Tooth S, Bullard JE et al (2017) The geomorphology of the anthropocene: emergence, status and implications. Earth Surf Process Landf 42:71-90. https://doi.org/10.1002/esp.3943

Brown AG, Tooth S, Chiverrell RC et al (2013) The Anthropocene: Is there a geomorphological case? Earth Surf Process Landf 38:431-434. https://doi.org/10.1002/esp.3368

Chang J, Slaymaker O (2002) Frequency and spatial distribution of landslides in a mountainous drainage basin: Western Foothills, Taiwan. CATENA 46:285-307. https://doi.org/10.1016/S0341-8162(01) 00157-6

Chen Y-J, Chang K-C (2011) A spatial-temporal analysis of impacts from human development on the Shih-men Reservoir watershed. Taiwan Int J Remote Sens 32:9473-9496. https://doi.org/10.1080/ 01431161.2011 .562253

Clauset A, Shalizi CR, Newman MEJ (2009) Power-law distributions in empirical data. SIAM Rev 51:661-703. https://doi.org/10.1137/070710111

Coker RJ, Fahey BD (1993) Road-related mass movement in weathered granite, Golden Downs and Motueka Forests, New Zealand: a note. J Hydrol (new Zealand) 31:65-69

DOKAP (2014) Doğu Karadeniz Projesi (DOKAP) Eylem Planı (2014-2018)

Dadson SJ, Hovius N, Chen H et al (2004) Earthquake-triggered increase in sediment delivery from an active mountain belt. Geology 32:733-736. https://doi.org/10.1130/G20639.1

Ersoy S (2017) 2016 Yılı Doğa Kaynaklı Afetler Yıllığı "Dünya ve Türkiye." Jeoloji Mühendisleri Odası Yayınları No: 129, Ankara (in Turkish)

Fan X, Domènech G, Scaringi G et al (2018) Spatio-temporal evolution of mass wasting after the $2008 \mathrm{Mw} 7.9$ Wenchuan earthquake revealed by a detailed multi-temporal inventory. Landslides 15:2325-2341. https://doi.org/10.1007/s10346-018-1054-5

Fan X, Scaringi G, Korup O et al (2019) Earthquake-induced chains of geologic hazards patterns mechanisms and impacts. Rev Geophys 57:421-503. https://doi.org/10.1029/2018RG000626

Fransen PJB, Phillips CJ, Fahey BD (2001) Forest road erosion in New Zealand: overview. Earth Surf Process Landf 26:165-174. https://doi.org/10.1002/1096-9837(200102)26:2\%3c165::AIDESP170\%3e3.0.CO;2-\#

Froude MJ, Petley DN (2018) Global fatal landslide occurrence from 2004 to 2016. Nat Hazards Earth Syst Sci 18:2161-2181. https://doi.org/10.5194/nhess-18-2161-2018

Guadagno F, Martino S, Scarascia Mugnozza G (2003) Influence of man-made cuts on the stability of pyroclastic covers (Campania, southern Italy): a numerical modelling approach. Environ Geol 43:371-384. https://doi.org/10.1007/s00254-002-0658-0

Guns M, Vanacker V (2014) Shifts in landslide frequency-area distribution after forest conversion in the tropical Andes. Anthropocene 6:75-85. https://doi.org/10.1016/j.ancene.2014.08.001

Guzzetti F, Malamud BD, Turcotte DL, Reichenbach P (2002) Power-law correlations of landslide areas in central Italy. Earth Planet Sci Lett 195:169-183. https://doi.org/10.1016/S0012-821X(01) 00589-1

Guzzetti F, Reichenbach P, Cardinali M, Galli M, Ardizzone F (2005) Probabilistic landslide hazard assessment at the basin scale. Geomorphology 72:272-299. https://doi.org/10.1016/j.geomorph.2005.06.002

Görüm T, Fidan S (2021) Spatiotemporal variations of fatal landslides in Turkey. Landslides. https://doi. org/10.1007/s10346-020-01580-7

Haigh MJ, Rawat JS, Bartarya SK (1989) Environmental indicators of landslide activity along the Kilbury Road, Nainital, Kumaun Lesser Himalaya. Mt Res Dev 9:25-33. https://doi.org/10.2307/ 3673462 
Hearn GJ, Shakya NM (2017) Engineering challenges for sustainable road access in the himalayas. Q J Eng Geol Hydrogeol 50:69-80. https://doi.org/10.1144/qjegh2016-109

Holcombe EA, Beesley MEW, Vardanega PJ, Sorbie R (2016) Urbanisation and landslides: hazard drivers and better practices. Proc Inst Civ Eng Civ Eng 169:137-144. https://doi.org/10.1680/jcien.15.00044

Huffman G, Stocker EF, T BD et al (2019) GPM IMERG final precipitation L3 1 day 0.1 degree x 0.1 degree V06. In: Ed. by Andrey Savtchenko, Greenbelt, MD, Goddard Earth Sci. Data Inf. Serv. Cent. (GES DISC). https://disc.gsfc.nasa.gov/datasets/GPM_3IMERGDF_06/summary. Accessed 23 Jul 2021

Jaboyedoff M, Michoud C, Derron MH et al (2018) Human-induced landslides: toward the analysis of anthropogenic changes of the slope environment. In: Stefano A, Leonardo C, Luciano P, Claudio S (eds) Landslides and engineered slopes. Experience, theory and practice. CRC Press Boca Raton, FL, USA, pp 217-232

Jones J, Boulton S, Bennett G et al (2020) Himalaya mass-wasting: impacts of the monsoon, extreme tectonic and climatic forcing, and road construction. In: EGU General Assembly 2020. Online, 4-8 May 2020

Khan SF, Kamp U, Owen LA (2013) Documenting five years of landsliding after the 2005 Kashmir earthquake, using repeat photography. Geomorphology 197:45-55. https://doi.org/10.1016/j.geomo rph.2013.04.033

Khattak GA, Owen LA, Kamp U, Harp EL (2010) Evolution of earthquake-triggered landslides in the Kashmir Himalaya, northern Pakistan. Geomorphology 115:102-108. https://doi.org/10.1016/j. geomorph.2009.09.035

Laimer HJ (2017) Anthropogenically induced landslides - A challenge for railway infrastructure in mountainous regions. Eng Geol 222:92-101. https://doi.org/10.1016/j.enggeo.2017.03.015

Larsen MC, Parks JE (1997) How wide is a road? The association of roads and mass-wasting in a forested montane environment. Earth Surf Process Landforms 22:835-848. https://doi.org/10.1002/ (sici)1096-9837(199709)22:9\%3c835::aid-esp782\%3e3.3.co;2-3

Lee S-G, Winter MG (2019) The effects of debris flow in the Republic of Korea and some issues for successful risk reduction. Eng Geol 251:172-189. https://doi.org/10.1016/j.enggeo.2019.01.003

Lewis SL, Maslin MA (2015) Defining the anthropocene. Nature 519:171-180. https://doi.org/10.1038/ nature 14258

Li Y, Wang X, Mao H (2020) Influence of human activity on landslide susceptibility development in the Three Gorges area. Nat Hazards 104:2115-2151. https://doi.org/10.1007/s11069-020-04264-6

Maharaj RJ (1993) Landslide processes and landslide susceptibility analysis from an upland watershed: a case study from St. Andrew, Jamaica, West Indies. Eng Geol 34:53-79. https://doi.org/10.1016/ 0013-7952(93)90043-C

Malamud BD, Turcotte DL, Guzzetti F, Reichenbach P (2004) Landslide inventories and their statistical properties. Earth Surf Process Landforms 29:687-711. https://doi.org/10.1002/esp.1064

McAdoo BG, Quak M, Gnyawali KR et al (2018) Roads and landslides in Nepal: how development affects environmental risk. Nat Hazards Earth Syst Sci 18:3203-3210. https://doi.org/10.5194/ nhess-18-3203-2018

Morin GP, Lavé J, France-Lanord C et al (2018) Annual sediment transport dynamics in the Narayani Basin, Central Nepal: assessing the impacts of erosion processes in the annual sediment budget. J Geophys Res Earth Surf 123:2341-2376. https://doi.org/10.1029/2017JF004460

NASA JPL (2013) NASA Shuttle Radar Topography Mission United States 1 Arc Second. NASA EOSDIS Land Processes DAAC, USGS Earth Resources Observation and Science (EROS) Center, Sioux Falls, South Dakota https://lpdaac.usgs.gov, Accessed date: 1 December 2019

Nefeslioglu HA, Gokceoglu C, Sonmez H, Gorum T (2011) Medium-scale hazard mapping for shallow landslide initiation: The Buyukkoy catchment area (Cayeli, Rize, Turkey). Landslides 8:459-483. https://doi.org/10.1007/s10346-011-0267-7

Owen LA, Kamp U, Khattak GA et al (2008) Landslides triggered by the 8 October 2005 Kashmir earthquake. Geomorphology 94:1-9. https://doi.org/10.1016/j.geomorph.2007.04.007

Parker RN, Densmore AL, Rosser NJ et al (2011) Mass wasting triggered by the 2008 Wenchuan earthquake is greater than orogenic growth. Nat Geosci 4:449-452. https://doi.org/10.1038/ngeo1154

Parker RN, Hancox GT, Petley DN et al (2015) Spatial distributions of earthquake-induced landslides and hillslope preconditioning in the northwest South Island, New Zealand. Earth Surf Dyn 3:501525. https://doi.org/10.5194/esurf-3-501-2015

Petley DN, Hearn GJ, Hart A et al (2007) Trends in landslide occurrence in Nepal. Nat Hazards 43:2344. https://doi.org/10.1007/s11069-006-9100-3

Planet Team (2017) Planet application program interface: in space for life on earth. San Francisco, CA. https://api.planet.com 
Poesen J (2018) Soil erosion in the anthropocene: research needs. Earth Surf Process Landf 43:64-84. https://doi.org/10.1002/esp.4250

Raja NB, Çiçek I, Türkoğlu N et al (2017) Landslide susceptibility mapping of the Sera River Basin using logistic regression model. Nat Hazards 85:1323-1346. https://doi.org/10.1007/ s11069-016-2591-7

Reis S, Nişanci R, Yomralioğlu T (2009) Designing and developing a province-based spatial database for the analysis of potential environmental issues in Trabzon, Turkey. Environ Eng Sci 26:123-130. https://doi.org/10.1089/ees.2007.0158

Rosser N, Kincey M, Oven K et al (2021) Changing significance of landslide hazard and risk after the 2015 Mw 7.8 Gorkha, Nepal earthquake. Prog Disaster Sci. https://doi.org/10.1016/j.pdisas.2021.100159

Rossi M, Cardinali M, Fiorucci F et al (2012) A tool for the estimation of the distribution of landslide area in R. In: EGU General Assembly Conference Abstracts. p 9438

Schmitt RG, Tanyas H, Nowicki Jessee MA et al (2017) An open repository of earthquake-triggered groundfailure inventories. Reston, VA

Şekercioğlu ÇH, Anderson S, Akçay E et al (2011a) Turkey’s globally important biodiversity in crisis. Biol Conserv 144:2752-2769. https://doi.org/10.1016/j.biocon.2011.06.025

Şekercioğlu ÇH, Anderson S, Akçay E, Bilgin R (2011b) Turkey's rich natural heritage under assault. Science 334:1637-1639

Stark CP, Guzzetti F (2009) Landslide rupture and the probability distribution of mobilized debris volumes. J Geophys Res Earth Surf 114:1-16. https://doi.org/10.1029/2008JF001008

Steffen W, Broadgate W, Deutsch L et al (2015) The trajectory of the anthropocene: the great acceleration. Anthr Rev 2:81-98. https://doi.org/10.1177/2053019614564785

Steffen W, Grinevald J, Crutzen P, John McNeill (2011) The Anthropocene: conceptual and historical perspectives. Philos Trans R Soc A Math Phys Eng Sci 369:842-867. https://doi.org/10.1098/rsta.2010. 0327

Tang C, Zhu J, Qi X, Ding J (2011) Landslides induced by the Wenchuan earthquake and the subsequent strong rainfall event: A case study in the Beichuan area of China. Eng Geol 122:22-33. https://doi.org/ 10.1016/j.enggeo.2011.03.013

Tanyaş H, Allstadt KE, van Westen CJ (2018) An updated method for estimating landslide-event magnitude. Earth Surf Process Landforms. https://doi.org/10.1002/esp.4359

Tanyaş H, van Westen CJ, Allstadt KE et al (2017) Presentation and analysis of a worldwide database of earthquake-induced landslide inventories. J Geophys Res Earth Surf. https://doi.org/10.1002/2017J F004236

Tanyaş H, van Westen CJ, Allstadt KE, Jibson RW (2019) Factors controlling landslide frequency-area distributions. Earth Surf Process Landf. https://doi.org/10.1002/esp.4543

Tarolli P, Calligaro S, Cazorzi F, Fontana GD (2013) Recognition of surface flow processes influenced by roads and trails in mountain areas using high-resolution topography. Eur J Remote Sens 46:176-197. https://doi.org/10.5721/EuJRS20134610

TSMS (2020) Turkish State Meteorological Service official data service for precipitation. https://mgm.gov. tr/sondurum/toplam-yagis.aspx. Accessed 30 Dec 2020

U.S. Geological Survey (2017) Search Earthquake Catalog

Valdiya KS (2014) Damming rivers in the tectonically resurgent Uttarakhand Himalaya. Curr Sci 106:1658-1668

Van Den Eeckhaut M, Poesen J, Govers G et al (2007) Characteristics of the size distribution of recent and historical landslides in a populated hilly region. Earth Planet Sci Lett 256:588-603. https://doi.org/10. 1016/j.eps1.2007.01.040

Vuillez C, Tonini M, Sudmeier-Rieux K et al (2018) Land use changes, landslides and roads in the Phewa Watershed, Western Nepal from 1979 to 2016. Appl Geogr 94:30-40. https://doi.org/10.1016/j.apgeog. 2018.03.003

WWF (2020) Kamilet Havzası Bir Doğa Müzesi Olarak Saklanmalı. https://www.wwf.org.tr/yayinlarimiz/ basin_bultenleri/?10060/Kamilet-Havzasi-Bir-Doga-Muzesi-Olarak-Saklanmali

Wasowski J (1998) Understanding rainfall-landslide relationships in man-modified environments: a casehistory from Caramanico Terme, Italy. Environ Geol 35:197-209. https://doi.org/10.1007/s002540050 306

Waters CN, Zalasiewicz J, Summerhayes C et al (2016) The Anthropocene is functionally and stratigraphically distinct from the Holocene. Science 351:aad2622. https://doi.org/10.1126/science.aad2622

Xu C, Xu X, Shyu JBH et al (2014) Landslides triggered by the 22 July 2013 Minxian-Zhangxian, China, Mw 5.9 earthquake: inventory compiling and spatial distribution analysis. J Asian Earth Sci 92:125142. https://doi.org/10.1016/j.jseaes.2014.06.014 
Yuksel E, Eminagaoglu O (2017) Flora Of The Kamilet Valley (Arhavi, Artvin, Turkey). Int J Ecosyst Ecol Sci 7:905-914

Publisher's Note Springer Nature remains neutral with regard to jurisdictional claims in published maps and institutional affiliations. 